\title{
Hubungan Usia dengan Estrogen Receptor pada Penderita Kanker Payudara di RSUD Dr. Pirngadi Medan Tahun 2018
}

\author{
Jumikha Tamara Sahmaulyana Sidauruk ${ }^{1}$, Ronald Sitohang ${ }^{2}$, Ade Pryta Simaremare ${ }^{3}$ \\ ${ }^{1}$ Mahasiswa, Fakultas Kedokteran Universitas HKBP Nommensen \\ ${ }^{2}$ Departemen IImu Bedah Fakultas Kedokteran Universitas HKBP Nommensen \\ ${ }^{3}$ Departemen Mikrobiologi Fakultas Kedokteran Universitas HKBP Nommensen \\ Korespondensi: Jumikha Tamara Sahmaulyana Sidauruk, Email: mikhasidauruk0620@gmail.com
}

\begin{abstract}
Background: Breast cancer is a malignancy in breast tissue that can be originated from ductal epithelium and lobules. It is the main cause of death from cancer suffered by women in the world. Age and hormonal are important risk factors for breast cancer where the longer a person is exposed to estrogen, the higher is the risk for breast cancer. The estrogen receptor is one of the main prognostic and predictive factors examined in breast cancer and can be determinant for hormonal therapy.
\end{abstract}

Objective: This study aimed to discover the relation between age and estrogen receptor in breast cancer patients of RSUD Dr.Pirngadi Medan in 2018.

Method: This research was an analytical study with a cross-sectional design. The research sample was 96 breast cancer patients by medical records of RSUD Dr.Pirngadi Medan in 2018 collected by a consecutive sampling method. Analysis of the data in this study was done by univariate to describe the characteristics of research subjects, while bivariate analysis used the chi-square test method to analyze the relationship between age and estrogen receptor.

Results: The patients with breast cancer in RSUD Dr.Pirngadi Medan 2018 was mostly $>40$ years old (79.2\%), with negative estrogen receptor hormonal status (53\%), status was married $(99 \%)$, and the highest level of education was high school (54.2\%). The results of the study showed that there was a relationship between age and estrogen receptor in breast cancer patients with $p$-value $=0.007$ ( $p$ value $<0,05$ ).

Conclusion: There was a significant relationship between age and estrogen receptors and estrogen receptors in breast cancer patients in RSUD Dr.Pirngadi Medan 2018.

Keywords: breast cancer; age; estrogen receptor

\begin{abstract}
Abstrak
Latar belakang: Kanker payudara merupakan keganasan pada jaringan payudara yang berasal dari epitel duktus maupun lobulusnya. Kanker payudara merupakan penyebab utama kematian akibat kanker pada wanita di dunia. Faktor usia dan hormonal merupakan faktor risiko penting terjadinya kanker payudara dimana semakin lama seseorang terpapar estrogen maka semakin tinggi risiko terjadinya kanker payudara. Estrogen receptor merupakan salah satu faktor prediktif utama yang diperiksa pada kanker payudara serta dapat menjadi salah satu penentu terapi hormonal.
\end{abstract}

Tujuan: Penelitian ini bertujuan untuk mengetahui hubungan antara usia dengan estrogen receptor pada penderita kanker payudara di RSUD Dr. Pirngadi Medan pada tahun 2018. 
Metode: Penelitian ini adalah penelitian analitik dengan desain cross sectional. Sampel penelitian adalah 96 pasien penderita kanker payudara yang diambil data rekam mediknya di RSUD Dr. Pirngadi Medan tahun 2018. Pengambilan sampel dilakukan dengan cara consecutive sampling. Analisa data menggunakan uji chi-square untuk menganalisis hubungan antara usia dengan estrogen receptor.

Hasil: Penderita kanker payudara di RSUD Dr. Pirngadi Medan tahun 2018 paling banyak berusia $>40$ tahun $(79,2 \%)$, dengan status hormonal estrogen receptor negatif $(53 \%)$, status perkawinan menikah (99\%), tingkat pendidikan SLTA $(54,2 \%)$. Secara statisik terdapat hubungan usia dengan estrogen receptor pada penderita kanker payudara dengan nilai $p=0,007(p<0,05)$.

Kesimpulan: Terdapat hubungan usia dengan estrogen receptor yang signifikan pada penderita kanker payudara di RSUD Dr. Pirngadi Medan tahun 2018.

Kata Kunci: Kanker payudara, usia, estrogen receptor.

\section{Pendahuluan}

Kanker adalah penyakit yang ditandai dengan pembentukan dan proliferasi sel-sel baru yang menghasilkan sel baru dengan ciri, bentuk, sifat, dan kinetiknya berbeda dengan sel asal yang normal. Sel-sel tersebut tumbuh liar dan terlepas dari sistem kendali pertumbuhan normal sehingga bentuk dan fungsi organ yang disusun olehnya menjadi rusak. ${ }^{1}$ Penyakit kanker merupakan salah satu penyebab kematian utama di seluruh dunia. Pada tahun 2012, sekitar 8,2 juta kematian disebabkan oleh kanker, dan kanker payudara menjadi salah satu penyebab terbesar kematian setiap tahunnya. ${ }^{2}$ Kanker payudara merupakan keganasan pada jaringan payudara yang dapat berasal dari epitel duktus maupun lobulusnya. Kanker ini merupakan penyebab kematian utama pada wanita. Pada penyakit ini, jaringan penunjang payudara tumbuh infiltratif dan destruktif, serta dapat bermetastasis. Kanker payudara menjadi salah satu masalah kesehatan yang penting di dunia. ${ }^{3,4}$

Menurut data International Agency for Research on Cancer (IARC) pada tahun 2018, kanker payudara merupakan penyebab utama kematian akibat kanker pada wanita 15,0\% di dunia, diikuti kanker paru-paru $13,8 \%$, kanker usus $9,5 \%$ dan kanker serviks $6,6 \% .{ }^{5} \mathrm{Di}$ Indonesia sendiri, berdasarkan data World Health Organization (WHO) pada tahun 2018, kanker payudara merupakan penyakit kanker dengan prevalensi tertinggi pada wanita dengan presentase $30,9 \%$ atau sekitar $58.256 .{ }^{6}$ Berdasarkan data dari Pusat Data dan Informasi Kementrian Kesehatan RI tahun 2013, Sumatera Utara memiliki prevalensi kanker payudara sebesar $0,4 \%$ atau sekitar 2.682 penderita dari total seluruh populasi wanita. ${ }^{2}$

Terdapat berbagai faktor yang diperkirakan meningkatkan risiko kanker payudara, antara lain faktor usia, genetik, hormonal, gaya hidup, lingkungan dan adanya riwayat tumor jinak. Faktor usia paling berperan dalam menimbulkan kanker payudara. ${ }^{7}$ Kanker payudara paling banyak terjadi pada wanita usia setengah baya dan lansia. ${ }^{8}$ Risiko akan terus meningkat tajam sampai dengan usia 40-45 tahun, lalu akan cenderung menetap setelah menopause.

Ketika wanita bertambah usia, maka produksi hormon estrogennya justru menurun. Perubahan tingkat keberadaan estrogen dalam jangka panjang meningkatkan risiko pengembangan sel-sel kanker payudara untuk tumbuh dan membelah diri. ${ }^{4}$. Faktor hormonal merupakan salah satu faktor risiko penting terjadinya kanker payudara. Peningkatan eksposur terhadap hormon estrogen akan meningkatkan risiko terjadinya kanker payudara. ${ }^{7}$

Pada pemeriksaan immunohistokimia, dapat diketahui nilai beberapa reseptor kanker payudara yaitu: estrogen, progesteron dan protein HER2/neu. ${ }^{9}$ Reseptor-reseptor ini dapat digunakan sebagai biomarker yang spesifik untuk menentukan prognosis pada penderita kanker payudara. Estrogen receptor merupakan salah satu faktor utama yang diperiksa pada kanker payudara serta dapat menjadi salah satu penentu terapi hormonal pada penderita. ${ }^{10}$ Reseptor ini diekspresikan secara berlebihan pada sekitar 70\% dari kanker payudara yang dikenal sebagai Estrogen Receptor Positive. ${ }^{11}$ Sekitar 2/3 wanita penderita kanker payudara berumur $<50$ tahun memiliki estrogen receptor negatif dan sekitar $80 \%$ wanita berusia $>50$ tahun memiliki estrogen receptor positif. ${ }^{10}$

Berdasarkan penelitian yang dilakukan oleh Azaman di Saudi, wanita yang lebih tua (>40 tahun) cenderung memiliki status Estrogen Receptor Positive 72,6\%. Dari penelitian ini disimpulkan bahwa terdapat hubungan antara usia dengan status estrogen receptor pada kanker payudara. ${ }^{12}$ Hasil penelitian yang diperoleh dari Estetika di Padang berbeda, dimana didapati hasil usia tidak memiliki perbedaan yang signifikan terhadap estrogen receptor dengan nilai $p$ sebesar 0,1 . Berdasarkan hasil analisis disimpulkan tidak terdapat hubungan antara usia dengan estrogen receptor. Secara kuantitatif dikatakan bahwa kadar estrogen receptor meningkat seiring dengan bertambahnya usia. Hal ini disebabkan karena semakin bertambahnya usia maka paparan estrogen yang dialami akan semakin banyak. ${ }^{13}$

Tujuan dilakukannya penelitian ini adalah untuk mengetahui hubungan antara usia dengan estrogen receptor pada penderita kanker payudara di RSUD Dr. Pirngadi Medan pada tahun 2018.

\section{Metode}

Penelitian ini merupakan penelitian analitik dengan metode crosssectional. Variabel independen pada penelitian adalah usia penderita kanker payudara dan variabel dependennya adalah status hormonal estrogen receptor. Sampel pada penelitian ini berjumlah 96 sampel yang diambil dari data rekam medik penderita kanker payudara di RSUD Dr. Pirngadi Medan periode Januari 2018 - Desember 2018 yang memenuhi kriteria inklusi dan eksklusi. Cara pemilihan sampel pada penelitian ini dilakukan 
dengan metode consecutive sampling. Kriteria inklusi pada peneltian ini adalah penderita kanker payudara wanita dan data rekam medik yang memuat informasi mengenai usia dan pemeriksaan imunohistokimia status hormonal estrogen saat pertama kali terdiagnosis kanker payudara, sedangkan kriteria eksklusi pada penelitian ini adalah penderita kanker payudara disertai kanker pada organ lainnya. Analisis data pada penelitian ini dilakukan dengan cara univariat dan bivariat. Analisis univariat digunakan untuk mendeskripsikan dan menganalisis karakteristik subjek penelitian, sedangkan analisis bivariat untuk menganalisis hubungan antara variabel usia terhadap variabel estrogen receptor. Metode analisis bivariat yang digunakan dalam penelitian ini adalah uji chi-square. Uji normalitas yang digunakan adalah uji kolmogorov-smirnov untuk menguji apakah data terdistribusi normal atau tidak.

\section{Hasil}

Gambaran karakteristik distribusi frekuensi usia penderita kanker payudara di RSUD Dr. Pirngadi Medan tahun 2018 dapat dilihat pada tabel 1. Berdasarkan tabel 1 dapat dilihat bahwa penderita kanker payudara lebih banyak pada kelompok usia $>40$ tahun sebanyak 76 orang $(79,2 \%)$ dibandingkan dengan kelompok usia $\leq 40$ tahun yaitu sebanyak 20 orang $(20,8 \%)$. Sampel pada penelitian ini paling banyak memiliki status hormonal estrogen receptor negatif yaitu 51 orang (53\%). Status perkawinan terbanyak dalam penelitian ini adalah menikah dengan jumlah 95 orang (99\%) dengan estrogen receptor positif pada status perkawinan menikah sebanyak 45 orang. Tingkat pendidikan sampel pada penelitian yang terbanyak adalah SLTA, sebanyak 52 orang $(54,2 \%)$.

Tabel 1. Deskripsi karakteristik subjek penelitian

\begin{tabular}{lcc}
\hline \multicolumn{1}{c}{ Karakteristik } & $\begin{array}{c}\text { Frekuensi } \\
(\mathbf{n})\end{array}$ & $\begin{array}{c}\text { Persentase } \\
(\%)\end{array}$ \\
\hline 1. Usia & & \\
$\quad$ 40 tahun & 20 & 20.8 \\
$\quad>40$ tahun & 76 & 79.2 \\
2. Status Hormonal & & \\
$\quad$ Estrogen Receptor & & \\
$\quad$ Positif & 45 & 47 \\
$\quad$ Negatif & 52 & 53 \\
3. Status Perkawinan & & \\
$\quad$ Menikah & 95 & 99 \\
$\quad$ Belum Menikah & 1 & 1 \\
4. Tingkat Pendidikan & & \\
SD & 14 & 14.6 \\
SLTP & 15 & 15.6 \\
SLTA & 52 & 54.2 \\
S-1 & 15 & 15.6 \\
\hline
\end{tabular}

Pada penelitian ini dilakukan analisis hubungan usia dengan estrogen receptor pada penderita kanker payudara di RSUD Dr. Pirngadi Medan tahun 2018. Sebelumnya dilakukan uji normalitas Kolmogorov-Smirnov dan didapati hasil signifikan skala usia, pendidikan terakhir, pemeriksaan estrogen receptor dan status perkawinan sebesar 0,000 . Karena data terdistribusi normal maka uji hipotesis yang dilakukan adalah chi-square. Hasil analisis dapat dilihat pada tabel 2. Hasil analisis menunjukkan terdapat hubungan usia dengan estrogen receptor pada penderita kanker payudara di RSUD Dr. Pirngadi Medan tahun 2018 dengan nilai $p=0,007$.

Tabel 2. Hubungan usia dengan estrogen receptor pada penderita kanker payudara

\begin{tabular}{ccccc}
\hline \multirow{2}{*}{ Usia } & \multicolumn{2}{c}{ Estrogen Receptor } & \multirow{2}{*}{ Total } & \multirow{2}{*}{$\boldsymbol{P}$ value } \\
\cline { 2 - 3 } & Positif & Negatif & & \\
\hline$\leq 40$ tahun & 4 & 16 & 20 & \multirow{2}{*}{$P=0.007$} \\
$>40$ tahun & 41 & 35 & 76 & \\
\hline Total & 45 & 51 & 96 & \\
\hline
\end{tabular}

\section{Pembahasan}

Pada penelitian ini didapati hasil penderita kanker payudara lebih banyak pada kelompok usia $>40$ tahun yaitu 76 orang $(79,2 \%)$. Hasil penelitian ini sesuai dengan penelitian yg dilakukan oleh Yanti di RSUP Dr. M. Djamil Padang tahun 2016 di mana didapati hasil kelompok usia yang lebih banyak terkena kanker payudara adalah $>40$ tahun yaitu sebanyak 78,3\%. ${ }^{14}$ Risiko utama kanker payudara adalah bertambahnya usia. Semakin lama seseorang hidup, semakin tinggi risiko kanker payudara karena fungsi organ maupun sel-sel dalam tubuh mengalami degenerasi serta paparan hormon estrogen yang panjang seiring bertambahnya usia. Kanker payudara mulai berkembang pesat saat umur 40-49 tahun sebelum wanita memasuki usia 50 tahun. Kemungkinan terkena kanker payudara meningkat seiring dengan meningkatnya umur. Lebih dari $75 \%$ kanker payudara terdiagnosa pada wanita berumur 40 tahun keatas. ${ }^{15}$ Kanker payudara jarang terjadi pada wanita berusia di bawah 30 tahun

Status hormonal estrogen receptor pada penelitian ini didapati lebih banyak pada estrogen receptor negatif yaitu 51 orang (53\%). Penelitian ini juga sejalan dengan penelitian yang dilakukan oleh Akbar di RSUP dr. Kariadi Semarang tahun 2016 dimana didapati hasil status hormonal estrogen receptor terbanyak adalah estrogen receptor negatif yaitu sebanyak 314 orang (70,4\%).16 Semakin bertambahnya usia seseorang maka paparan estrogen yang dialami akan lebih banyak. ${ }^{17}$ Tingginya kadar estrogen pada jaringan payudara wanita post menopause seringkali dianggap berasal dari tingginya uptake dari hormon dalam sirkulasi. ${ }^{18}$ Sekitar dua pertiga wanita penderita kanker payudara masuk pada usia menopause (49 - 51 tahun) mempunyai ekspresi estrogen receptor negatif,sementara sekitar $80 \%$ kanker payudara pada wanita post menopause yaitu berusia $>51$ tahun adalah estrogen receptor positif. ${ }^{17}$

Analisis hubungan usia dengan estrogen receptor pada pasien kanker payudara dilakukan dengan menggunakan uji chi-square dan diperoleh nilai $p=0,007$, dimana $p<0,05$ secara statistik menunjukkan bahwa terdapat hubungan usia dengan estrogen receptor pada penderita kanker payudara di RSUD Dr. Pirngadi Medan. Hasil penelitian ini sejalan dengan penelitian yang dilakukan Azaman di Arab tahun 2016 dengan hasil terdapat hubungan usia dengan estrogen receptor. ${ }^{12}$ Penelitian yang dilakukan Prastyo dari Universitas Muhammadiyah Surakarta tahun 2019 juga menyatakan terdapat hubungan antara usia dengan estrogen receptor. Berdasarkan data yang diperoleh, semakin bertambahnya usia, status hormonal estrogen positif semakin meningkat. Peningkatan risiko ini terjadi karena pada usia tersebut wanita akan mengalami perubahan siklus menstruasi 
yang membuat mereka tidak berovulasi maupun tetap berovulasi namun tidak menghasilkan hormon progesteron yang mencukupi sehingga hormon estrogenlah yang akan meningkat. Risiko terjadinya kanker payudara bertambah sebanding dengan pertambahan usia karena pengaruh paparan hormon estrogen yang lama. ${ }^{19}$ Penelitian ini masih memiliki banyak keterbatasan. Beberapa rekam medis tidak memiliki informasi yang lengkap. Bagi peneliti selanjutnya agar dapat menambah jumlah sampel dan jumlah variabel agar hasil penelitian semakin akurat.

\section{Kesimpulan}

Terdapat hubungan usia dengan estrogen receptor pada penderita kanker payudara di RSUD Dr.Pirngadi Medan tahum 2018. Semakin bertambahnya usia, status hormonal estrogen receptor positif semakin meningkat.

\section{Daftar Pustaka}

1. Rasjidi I. Buku Ajar Onkologi Klinik. Nugroho AW, editor. Jakarta: EGC; 2013. hal 1.

2. Kementrian Kesehatan Republik Indonesia. Profil Kesehatan Indonesia Tahun 2016. Jakarta; 2017. hal 2

3. Komite Penanggulangan Kanker Nasional. Panduan Penatalaksanaan Kanker Payudara. Jakarta; Tersedia pada http://kanker.kemkes.go.id/guidelines_read.php?id=2\&cancer=1

4. Savitri A. Kupas Tuntas Kanker Payudara, Leher Rahim \& Rahim. Mona, editor. Yogyakarta: Pustaka Baru Press; 2015.

5. World Health Organization. Breast [Internet]. 2018. Tersedia pada: http://gco.iarc.fr/today

6. Cancer Country Profiles [Internet]. World Health Organization. 2019. Tersedia pada: https://gco.iarc.fr/today/home

7. Jong D. Buku Ajar IImu Bedah. 3rd ed. Sjamsuhidajat R, editor. Jakarta: EGC; 2012.hal.479-80
8. Fujin C, Zhongli C, Minshan C. Buku Ajar Onkologi Klinis. Edisi 2. Jakarta: Fakultas Kedokteran Indonesia.hal.366-82

9. Bickley LS. Bates Buku Ajar Pemeriksaan Fisik dan Riwayat Kesehatan. Edisi 8. Hartono A, editor. Jakarta: EGC; 2012. hal.309-10

10. Putri N. Hubungan Antara Usia dan Body Mass Index (BMI) dengan Fenotip Molekuler Estrogen Receptor (ER) pada Pasien Invasive Breast Carsinoma of No Special Type (NST) di Rumah Sakit PKU Muhammadiyah Surakarta [tesis]. Universitas Muhammadiyah Surakarta; 2018.

11. Chorida L. Densitas Mamografi Metode Nilai Ambang, Kadar Estradiol, dan Polimorfisme Receptor Estrogen Sebagai Prediktor Kanker Payudara [disertasi]. Universitas Gadjah Mada; 2013.

12. Alzaman A. Correlation Between Hormone Receptor Status and Age, and its Prognostic Implications in Breast Cancer Patients in Bahrain. Saudi Med. 2016;37(1).

13. Estetika S, Harahap WA, Deddy Saputra. Pengaruh Faktor Resiko Terhadap Ekspresi Receptor Estrogen Pada Penderita Kanker Payudara di Kota Padang. J Kesehat Andalas. 2018;7(4).

14. Yanti M. Faktor Risiko Kanker Payudara Pada Wanita di Poliklinik Bedah RSUP Dr. M. Djamil Padang Tahun 2016. Universitas Andalas; 2016.

15. Lincoln J, Wilensky. Kanker Payudara Diagnosis dan Solusinya. Jakarta: Prestasi Pustakaraya; 2008.

16. Firasi AA, Yudhanto E. Hubungan Usia Terhadap Derajat Diferensiasi Kanker Payudara Pada Wanita. J Kedokt Diponegoro. 2016;5(4).

17. Payne SJL, Bowen RL, Jones JL, C A Wells. Predictive Markers In Breast Cancer-the Present. J Compil. 2008; 52:82-90.

18. Suparman E.Peran Estrogen Dan Progesteron Terhadap Kanker Payudara. Junal Biomedik (JBM). 2014;6(3):141-8.

19. Sulistiyowati. Stadium Kanker Payudara Ditinjau Dari Usia Dan Paritas Ibu Di Unit Rawat Jalan RSUD Dr. Soegiri Kabupaten Lamongan. Surya. 2012;3(13). 